ПАРХОМЕНКО Є. О., магістрант, ПАРХОМЕНКО Л. О., канд. техн. наук, доцент (Український державний університет залізничного транспорту)

\title{
Формування інформаційно-керуючої системи стратегічного планування швидкісних пасажирських перевезень на залізничному транспорті
}

Аналіз реалізащії останніх проектів підвищення швидкості руху пасажирських поӥздів у чинній системі управління залізничними пасажирськими перевезеннями України дає змогу зробити такі висновки: рішення щодо розвитку залізничної мережі приймаються розрізнено, не взаємопов'язано між собою $і$ без комплексної оцінки їх впливу в довгостроковому періоді функціонування мережі; не існує иентралізованої системи стратегічного управління пасажирськими перевезеннями на залізничному транспорті, рімення приймаються не узгоджено з основними структурними підрозділами, щуо здійснюють пасажирські перевезення; не існує теоретично обгрунтованих техніко-економічних розрахунків щзодо ефективності впровадження різних варіантів розвитку мережі залізничних пасажирських перевезень. Вищенаведені недоліки рішення задач розвитку топології залізничної мережі доводять необхідність створення Відділу стратегічного планування в межах Державної адміністрації залізничного транспорту України для реалізаџї системи стратегічного управління пасажирськими перевезеннями.

Для оптимізації каналів збору інформації та забезпечення підтримки прийняття стратегічних рімень на етапах аналізу, оцінки, вибору альтернатив та контролю виконання стратегії, щчо забезпечують взаємозв'язок всіх рівнів управління, у статті запропоновано створити Автоматизовану систему Стратегічного управління пасажирськими перевезеннями з реалізачією системи підтримки прийняття рішень для стратегічного планування швидкісних пасажирських перевезень на залізничному транспорті.

Ключові слова: залізничний транспорт, пасажирські перевезення, стратегія, структура управління, топологія мережі.

\begin{tabular}{l}
\hline Вступ \\
\hline \multicolumn{3}{c}{ Зважаючи на тривалий часовий період планування } \\
та масштабність рішення задач розподілу \\
пасажиропотоків швидкісних та високошвидкісних \\
поїздів з урахуванням розвитку топології залізничної \\
мережі України, метою даної роботи є удосконалення \\
структури управління залізничними пасажирськими \\
перевезеннями на основі створення системи \\
стратегічного управління. Під стратегічним \\
управлінням розуміється процес розробки та \\
впровадження рішень щодо розвитку топології \\
залізничної мережі швидкісних перевезень, які \\
пов'язані у просторі (за виконавцями) і в часі (за \\
термінами), націлених на виконання стратегічних \\
завдань з метою підтримання здатності до виживання \\
та ефективного функціонування галузі залізничних \\
перевезень в умовах нестабільного зовнішнього \\
середовища.
\end{tabular}

\begin{tabular}{l}
\hline Аналіз досліджень та постановка задач \\
Об'єктом стратегічного управління є процес \\
розвитку топології залізничної мережі, тоді як \\
предметом мають стати інноваційні проекти \\
підвищення швидкості руху пасажирських поїздів на \\
залізницях України. Система стратегічного управління \\
має об'єднувати основні структури, які пов'язані з \\
організацією залізничних перевезень в Україні, \\
зокрема Міністерство інфраструктури України, \\
Головне пасажирське управління Державної \\
адміністрації залізничного транспорту, компанію \\
«Українська залізнична швидкісна компанія” (УзШК), \\
залізниці. В межах горизонтального та вертикального \\
об'єднання в системі стратегічного управління стане \\
можливим узгодити та виробити єдину позицію \\
розвитку залізничної мережі з урахуванням пошуку \\
компромісу між різними варіантами розвитку мережі. \\
Особливості процесу стратегічного планування: \\
- процес організації перевезень пасажирів на \\
залізничному транспорті розглядається як цілісна \\
система; усі відомства, компанії, державні \\
підприємства, що пов’язані з даною сферою діяльності, \\
мають розглядатися як взаємопов'язані і взаємодіючі \\
підсистеми та елементи;
\end{tabular}


- концентрація уваги на тривалому періоді в три, п'ять і більше до 20 років;

- обов'язкове визначення ключових напрямів розвитку системи пасажирських перевезень країни;

- формування потенціалу майбутньої успішної діяльності галузі;

- створення основи для оперативного планування та прийняття поточних управлінських рішень;

- активізація спільної діяльності вищого керівництва щодо визначення та реалізації майбутнього.

Стратегічне управління можна виразити п'ятьма функціями:

- планування стратегії;

- організація виконання стратегічних планів;

- координація дій з реалізації стратегічних завдань;

- мотивація на досягнення стратегічних результатів;

- контроль за процесом виконання стратегії.

Однією 3 найбільш важливих функцій стратегічного управління є стратегічне планування це процес вибору цілей галузі та шляхів їх досягнення. В межах планування важливим етапом $\epsilon$ прогнозування. Прогнозування передує, власне, складанню стратегічних планів. Воно грунтується на проведенні аналізу широкого кола внутрішніх i зовнішніх факторів (умов) функціонування системи залізничних пасажирських перевезень 3 метою передбачення можливості розвитку та оцінки ризику. Систематичний прогноз дає змогу виробити обгрунтований підхід до стратегії розвитку топології залізничної мережі.

У прогнозуванні традиційно використовуються три виміри: час, напрямок (тенденції майбутнього) i величина (наскільки істотними будуть зміни). Для підвищення точності прогнозування важливим $\epsilon$ проведення аналізу зовнішніх та внутрішніх факторів, що впливають на стратегію розвитку залізничної мережі. 3 урахуванням результатів проведеного аналізу керівництво підприємства формулює місію (сферу надання послуг, глобальну мету), визначає перспективи розвитку залізничної мережі та розробляє стратегію. Погодження стратегічних цілей Укрзалізниці 3 результатами діяльності окремих підрозділів здійснюється за допомогою розроблення необхідної програми дій i складання бюджету. Бюджетування містить вартісну оцінку програми i розподіл ресурсів.

Координація дій керівництва ПАТ «Укрзалізниця» та "УЗШК” $з$ формування та реалізації генеральної стратегії полягає в узгодженні стратегічних рішень різних рівнів і послідовної консолідації цілей i стратегій структурних підрозділів на більш високих щаблях управління (Мінінфраструктури, Кабінету Міністрів України).
Мотивація як функція стратегічного управління пов'язана 3 розробкою системи стимулів, що спонукають до досягнення поставлених стратегічних результатів. Контроль полягає в безперервному спостереженні за процесом реалізації стратегічних планів. Він покликаний завчасно визначати небезпеки, що насуваються, виявляти помилки і відхилення від прийнятих стратегій і політики підприємства. Метою даного дослідження є вирішення задачі удосконалення структури управління залізничними пасажирськими перевезеннями на основі створення системи стратегічного управління, що дасть змогу підвищити ефективність процесу розроблення та впровадження рішень щодо розвитку топології залізничної мережі швидкісних перевезень.

\section{Основний матеріал}

Реалізація функцій стратегічного управління здійснюється за допомогою розробки i прийняття стратегічних рішень. Стратегічними рішеннями називають управлінські рішення, які орієнтовані на майбутне i закладають основу для прийняття оперативних рішень, пов'язані зі значною невизначеністю, оскільки враховують неконтрольовані зовнішні фактори, і пов'язані із залученням значних ресурсів, а також можуть мати надзвичайно серйозні, довгострокові наслідки для системи залізничних перевезень пасажирів.

Реалізація стратегії є критичним процесом, тому що саме він у випадку успішного здійснення приведе Укрзалізницю до досягнення поставлених цілей. Реалізація стратегії здійснюється через розробку програм, бюджетів і процедур, які можна розглядати як середньострокові і короткострокові плани реалізації стратегії.

Оцінка і контроль виконання стратегії $є$ логічно останнім етапом, що здійснюється у стратегічному управлінні. Цей процес забезпечує стійкий зворотний зв'язок між тим, як йде процес досягнення цілей, i цілями організацій, що здійснюють процес перевезення пасажирів.

Основні завдання контролю [2]:

- визначення того, що і за якими показниками перевіряти;

- здійснення оцінки стану контрольованого об'єкта відповідно до прийнятих стандартів, нормативів.

Вищеописані принципи формування системи стратегічного управління залізничними пасажирськими перевезеннями необхідно застосовувати для підвищення ефективності функціонування транспортних компаній, які здійснюють пасажирські перевезення на залізницях України.

Процес вибору напрямків розвитку системи залізничних пасажирських перевезень є складаним i залежить від суспільних вимог, економічних та 
політичних можливостей тощо. Аналіз реалізації останніх проектів підвищення швидкості руху пасажирських поїздів у чинній системі управління залізничними пасажирськими перевезеннями України дає змогу зробити такі висновки:

- рішення щодо розвитку залізничної мережі приймаються розрізнено, не взаємопов'язано між собою та без комплексної оцінки їх впливу в довгостроковому періоді функціонування мережі;

- не існує централізованої системи стратегічного управління пасажирськими перевезеннями на залізничному транспорті, рішення приймаються не узгоджено 3 основними структурними підрозділами, що здійснюють пасажирські перевезення;

- не існує теоретично обгрунтованих технікоекономічних розрахунків щодо ефективності впровадження різних варіантів розвитку мережі залізничних пасажирських перевезень.

Вищенаведені недоліки рішення задач розвитку топології залізничної мережі доводять необхідність створення спеціального структурного підрозділу в межах Державної адміністрації залізничного транспорту України для реалізації системи стратегічного управління пасажирськими перевезеннями.

Умовою реалізації ефективної структури стратегічного управління $є$ необхідність урахування послідовності процесу розробки і прийняття рішень при плануванні та управлінні маршрутами прямування швидкісних пасажирських поїздів 3 урахуванням розвитку топології залізничної мережі, що складається 3 таких елементів:

- аналіз структури та обсягів існуючих пасажиропотоків на мережі на основі зібраної i відповідним чином обробленої інформації;

- моделювання попиту пасажирів на швидкісні поїзди та визначення матриць кореспонденцій між основними містами на залізничній мережі;

- моделювання стратегічного розвитку мережі швидкісних перевезень та вибір напрямків для впровадження швидкісного руху;

- проведення техніко-економічного обгрунтування введення швидкісних поїздів;

- аналіз ефективності курсування швидкісних поїздів на мережі та виявлення існуючих і очікуваних відхилень від нормальних умов здійснення перевізного процесу;

- розробка можливих варіантів (стратегій) ліквідації наявних i запобігання очікуваним відхиленням від нормальних умов здійснення перевізного процесу на основі моделювання розвитку мережі швидкісних перевезень;

- вибір оптимального рішення i його документальне оформлення у вигляді наказу, вказівки, рекомендації тощо;

- контроль за виконанням прийнятих рішень.
Вищенаведені етапи управління швидкісними пасажирськими перевезеннями доводять необхідність створення єдиного органу стратегічного управління, який надають можливість узгодити та скоординувати стратегічні рішення зі всіма гравцями ринку пасажирських перевезень у межах горизонтальних та вертикальних зв'язків.

Беручи до уваги, що компанією, яка управляє інфраструктурою залізничної мережі та приймає рішення щодо розвитку мережі, $є$ Укрзалізниця, базовою платформою реалізації системи стратегічного управління запропоновано прийняти саме іiі. В роботі пропонується в складі Головного пасажирського управління (ЦЛ) створити Відділ стратегічного планування. Організаційну структуру Відділу стратегічного планування запропоновано реалізувати за лінійно-функціональним принципом. До складу Відділу мають входити два підрозділи: група стратегічного планування та група організаційного розвитку (рис. 1).

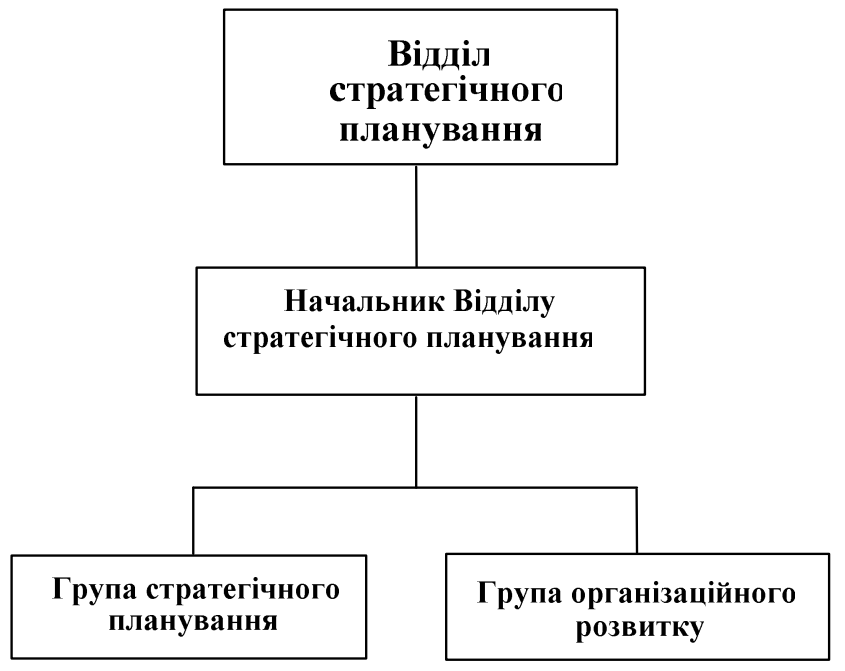

Рис. 1. Організаційна структура

Відділу стратегічного планування

Керує Відділом стратегічного планування Начальник Відділу стратегічного планування, якому підпорядковуються Провідний спеціаліст 3 ключовими показниками діяльності; провідний спеціаліст групи планування; фахівець групи планування; провідний спеціаліст групи організаційного розвитку; фахівець групи організаційного розвитку.

Головною метою Відділу стратегічного планування $\epsilon$ розвиток системи стратегічного управління за рахунок впровадження Інноваційних проектів підвищення швидкості руху поїздів, удосконалення якості послуг з перевезення пасажирів у межах довгострокового періоду планування за умови підвищення конкурентоспроможності залізничного транспорту та фінансової стабільності. 
І Н Ф О Р М А Ц Й Н О - КЕ Р У Ю Ч І С И С ТЕ МИ Н А З А Л І З Н ИЧ Н О М У Т Р А Н С П О Р Т І

Завданнями Відділу стратегічного планування є організація i управління процесом стратегічного планування сегмента залізничних пасажирських перевезень; розвиток системи організаційного управління (координація стратегічних цілей між усіма учасниками ринку); створення та розвиток системи збалансованих показників.

У рамках виконання завдання 3 організації та управління процесом стратегічного планування Відділ стратегічного планування виконує такі функції, як:

- організація, координація, вдосконалення та контроль єдиної системи планування діяльності у сфері залізничних пасажирських перевезень;

- підготовка Концепції (Стратегіï) розвитку топології залізничної мережі пасажирських перевезень;

- розробка Стратегічного плану розвитку на рік та 3 перспективою на 20 років;

- координація розробки планів заходів, пунктів стратегічного плану;

- координація розробки календарних планів заходів за функціональними напрямками;

- моніторинг щодо виконання планів заходів;

- ведення бази архівів Стратегічних планів розвитку залізничної мережі та Концепцій розвитку;

- вивчення, аналіз та впровадження в діяльність Укрзалізниці найкращих практик планування пасажирських перевезень;

- координація підготовки щомісячного звіту.

Відділ стратегічного планування має взаємодіяти 3 провідними фахівцями компанії ДП “УЗШК”, оскільки ця компанія $€$ власником парку швидкісних пасажирських поїздів та пунктів їх технічного сервісу. Крім того, важливою є взаємодія фахівців Відділу стратегічного планування Укрзалізниці 3 Департаментом державної політики в галузі залізничного транспорту та Управлінням стратегічного розвитку інфраструктури та науково-технічної політики Міністерства інфраструктури України, оскільки важливі рішення щодо фінансування та реалізації Проектів підвищення швидкості руху пасажирських поїздів приймаються саме в цьому відомстві.

\section{Вимоги до формування інформаційно-керуючої системи для стратегічного планування швидкісних пасажирських перевезень на залізничному транспорті.}

Реалізувати систему стратегічного управління неможливо без розвиненої інформаційної платформи, яка надасть можливість оптимізувати канали збору інформації та забезпечити підтримку прийняття стратегічних рішень на етапах аналізу, оцінки та вибору альтернатив і контролю виконання стратегії, що забезпечують взаємозв'язок усіх рівнів управління. Механізмом реалізації інформаційного простору $\epsilon$ інформаційно-керуюча система (ІКС), яка являє собою багаторівневу інформаційну систему, що гарантує автоматизоване управління всіма підсистемами системи пасажирських перевезень.

На сьогодні на залізницях України функціонує Автоматизована система керування пасажирськими перевезеннями на залізницях України (АСК ПП УЗ), що являє собою територіально розгалужену інформаційно-аналітичну систему, яка працює в реальному масштабі часу за єдиним технологічним процесом обслуговування пасажирів i працівників залізниць. Метою створення і розвитку АСК ПП УЗ є автоматизація цілої низки технологічних функцій для об'єднання в одній системі процесів, що пов'язані 3 обліком місць у поїздах, оформленням проїзду пасажирів та перевезень багажу, обліком ремонту та експлуатації пасажирських вагонів, інформаційним забезпечення пасажирів та персоналу залізниць, фінансовим обліком та розподілом доходів, статистичним аналізом показників.

АСК ПП УЗ $є$ інтегрованою системою, до якої входять такі блоки автоматизованих систем складових АСК ПП УЗ: АС „Керування обчислювальним процесом”; АС „Оформлення проїзду (перевезень)”; АC „Облік доходних надходжень та їх розподіл”; АC „Інформаційно-пошукові системи”; АC „Аналітично-інформаційна робота”; АC „Регулювання транспортним процесом”; АC „Термінальне обладнання”; АC „Вагонний парк”; АC „Вокзальне господарство”; АC „Комплексна система захисту інформації”; АС „Сервіс”.

Аналіз функцій підсистем показав, що АСК ПП УЗ охоплює лише рівні оперативного i тактичного управління перевізним процесом через рішення функціональних задач на автоматизованих робочих місцях (терміналах), які встановлюються для всіх працівників залізниць, діяльність яких пов'язана 3 використанням можливостей системи. Водночас в АСК ПП УЗ не існує реалізації функцій стратегічного управління пасажирськими перевезеннями на залізничному транспорті України.

Програма створення IКC передбачає декілька етапів [7]: удосконалення та розвиток існуючої системи збору та обробки інформації; розвиток ІКС 3 метою автоматизації підтримки прийняття рішень. Головною метою другого етапу $є$ створення системи підтримки прийняття рішень (СППР) як підсистеми IКC [4], що дозволить підвищити якість оперативних, тактичних та стратегічних рішень. Перший етап можна розглядати як процес розвитку IКС, який у цей час вже реалізовано на залізничному транспорті України (АСК ПП УЗ). Водночас питання розробки СППР до сих пір є одним із найбільш актуальних та необхідних напрямків підвищення якості управління.

Виходячи із вищесказаного в роботі запропоновано розробити Автоматизовану систему Стратегічного управління пасажирськими перевезеннями 3 
реалізацією системи підтримки прийняття рішень для стратегічного планування швидкісних пасажирських перевезень на залізничному транспорті на основі формування локальної комп'ютерної мережі 3 розробкою комплексу додаткових задач на АРМ інженерного персоналу, що інтегрована до системи АСК ПП УЗ.

Створення та впровадження СППР в ІКС потребує поетапної розробки сукупності всіх підсистем, що забезпечує функціонування СППР: технічного, математичного, програмного та інформаційного, організаційного забезпечення. Під СППР для стратегічного планування швидкісних пасажирських перевезень на залізничному транспорті розуміється система, що включена в організаційне середовище вищеописаної системи стратегічного управління на залізничному транспорті України. Схема АC Стратегічного управління пасажирськими перевезеннями 3 реалізацією системи підтримки прийняття рішень для стратегічного планування швидкісних пасажирських перевезень на залізничному транспорті наведена на рис. 2.

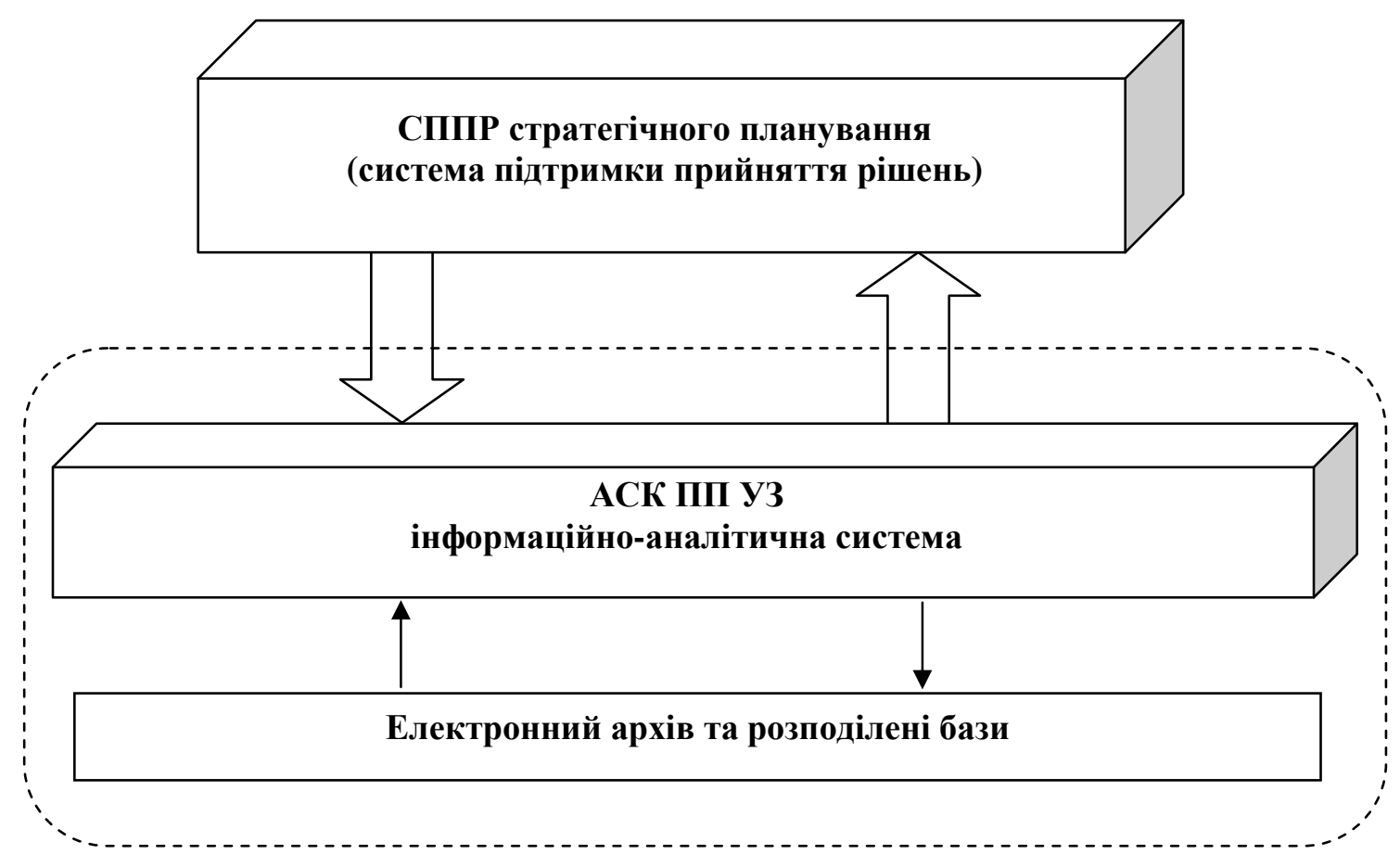

Рис. 2. Схема інформаційно-керуючої системи стратегічного управління пасажирськими перевезеннями

В основі СППР для стратегічного планування швидкісних пасажирських перевезень лежить комплекс взаємопов’язаних математичних моделей, що використовуються на різних етапах планування стратегії розвитку топології залізничної мережі пасажирських перевезень. На першому етапі виконується збір інформації для аналізу та прогнозування кореспонденцій пасажиропотоків між містами. В межах рішення даної задачі АC Стратегічного планування швидкісних пасажирських перевезень має інформаційно взаємодіяти з усіма АС чинної системи АСК ПП УЗ. Отримані дані є вхідною інформацією для застосування математичної моделі прогнозування кореспонденцій пасажирів в умовах впровадження залізничного швидкісного пасажирського сполучення на основі нечітких реляційних обчислень. На наступному етапі на базі використання даних щодо прогнозів попиту на перевезення здійснюється визначення раціональної топології мережі швидкісних залізничних пасажирських перевезень.

Отримані результати щодо варіантів розвитку топології залізничної мережі та розподілу поїздопотоків швидкісних поїздів за допомогою створення в межах СППР інформаційної платформи розсилаються на їх АРM причетним працівникам різних організацій, що входять в організаційну структуру Системи стратегічного управління пасажирськими перевезення на залізничному транспорті України. Крім того, в межах СППР має бути реалізований календарний планувальник 3 можливістю встановлення планів заходів стратегічного плану зі встановленням дат та строків. Кожна зі структур, що функціонує в межах Укрзалізниці, має вести моніторинг даних планів, вказувати строки виконання або причини невиконання встановленого плану заходів. Таким чином буде реалізовано функції моніторингу та аналізу виконання стратегічних планів розвитку мережі. 


\begin{tabular}{l}
\hline Висновки \\
\hline Для інформаційної підтримки організаційної \\
структури управління у статті запропоновано створити \\
Автоматизовану систему Стратегічного управління \\
пасажирськими перевезеннями 3 реалізацією системи \\
підтримки прийняття рішень для стратегічного \\
планування швидкісних пасажирських перевезень на \\
залізничному транспорті. Сформувати дану СППР \\
запропоновано на основі створення $\quad$ локальної \\
компютерної мережі 3 розробкою комплексу \\
додаткових задач на АРМ інженерного персоналу, що \\
інтегрована до системи АСК ПП УЗ.
\end{tabular}

\section{Список використаних джерел}

1. Перспективи використання інтелектуальних технологій на залізничному транспорті [Текст] / Т. В. Бутько, А. В. Прохорченко, С. І. Музикіна, Л. А. Пархоменко // Програма III міжнар. наук.практ. конф. «Інноваційні технології на залізничному транспорті» (Тель-Авів, 26 лютого 4 березня 2012 р.). - C. 3.

2. Garth Saloner, Andrea Shepard, Joel Podolny. Strategic Management. - John Wiley \& Sons, 2000. $464 \mathrm{c}$.

3. Томпсон-мл., Артур А. Стратегический менеджмент: концепции и ситуации для анализа = Strategic Management: Concepts and Cases [Текст] / Артур А. Томпсон-мл., А. Дж. Стрикленд III. 12-е изд. - М. : «Вильямс», 2007. - 328 с.

4. Гаскаров, Д. В. Интеллектуальные информационные системы [Текст]: учеб. для вузов / Д. В. Гаскаров. - М. : Высш. шк., 2003. $431 \mathrm{c}$.

5. Пьявченко, Т. А. Автоматизированные информационно-управляющие системы [Текст] / Т. А. Пьявченко, В. И. Финаев. - Таганрог : Изд- во ТРТУ, 2007. - 271 с.

6. Пасажирські перевезення (залізничний транспорт) [Текст] : навч. посібник / Т.В. Бутько, О. А. Малахова, А. В. Прохорченко, Д. В. Константінов; за ред. Т. В. Бутько; [УкрДАЗТ]. - Харків : Райдер, 2014. - 260 с.

7. Гимади, Э. Х. Математические модели и методы принятия решений [Текст] / Э. Х. Гимади, Н. И. Глебов. - Новосибирск : НГУ, 2008. - 144 с.

8. Вендров, А. М. Современные методы и средства проектирования информационных систем [Текст] / А. М. Вендров. - М. : Финансы и статистика, 1998. $-176 \mathrm{c}$.

Yevhen Parkhomenko, Larysa Parkhomenko. Formation of the information and control system of strategic planning of speed passenger transportation on railway transport. An analysis of the implementation of recent projects to increase the speed of passenger trains in the existing system of managing rail passenger transportation in Ukraine allows us to draw the following conclusions: decisions on the development of the railway network are taken in a scattered, not interconnected and without a comprehensive assessment of their impact in the long-term operation of the network; there is no centralized system of strategic management of passenger transportation on the railway transport, decisions are taken not in agreement with the main structural units that carry out passenger transportation; there are no theoretically feasible technical and economic calculations regarding the effectiveness of implementing various options for the development of the rail passenger transport network. The above mentioned drawbacks of solving the problems of the development of the railway topology prove the necessity of establishing a Strategic Planning Division within the State Administration of Railway Transport of Ukraine for the implementation of the system of strategic management of passenger transportation.

In order to optimize the channels of information gathering and to support the adoption of strategic decisions at the stages of analysis, evaluation, selection of alternatives and control of strategy implementation, ensuring the interconnection of all levels of management, the article proposes to create the Automated System of Strategic Management of Passenger Transport with the implementation of the decision support system for strategic planning of high-speed passenger transport by rail.

Key words: railway transport, passenger transportation, strategy, management structure, topology of the network.

\section{Пархоменко Е. А., Пархоменко Л. А. Формирование информационно-управляющей системы} стратегичного планирования скоростных пассажирских перевозок на железнодорожном транспорте. Анализ реализации последних проектов повышения скорости движения пассажирских поездов в действующей системе управления железнодорожными пассажирскими перевозками Украины позволяет сделать следующие выводы: решения по развитию железнодорожной сети принимаются разрозненно, а не взаимосвязано между собой и без комплексной оценки их влияния в долгосрочном периоде функционирования сети; не существут централизованной системы стратегического управления пассажирскими перевозками на железнодорожном транспорте, решения принимаются не согласовано с основными структурными подразделениями, осуществляющими пассажирские перевозки; не существует теоретически обоснованных технико-экономических расчетов по эффективности внедрения различных вариантов развития сети железнодорожных пассажирских перевозок. Приведеные выше недостатки решения 
задач развития топологии железнодорожной сети доказывают необходимость создания Отдела стратегического планирования в рамках Государственной администрации железнодорожного транспорта Украины для реализации системы стратегического управления пассажирскими перевозками.

Для оптимизации каналов сбора информации и обеспечения поддержки принятия стратегических решений на этапах анализа, оценки, выбора альтернатив и контроля выполнения стратегии, обеспечивающих взаимосвязь всех уровней управления, в статье предложено создать Автоматизированную систему Стратегического управления пассажирскими перевозками с реализацией системы поддержки принятия решений для стратегического планирования скоростных пассажирских перевозок на железнодорожном транспорте.

Ключевые слова: железнодорожный транспорт, пассажирские перевозки, стратегия, структура управления, топология сети.

Надійшла 24.09.2018 p.

Пархоменко Свген Олександрович, магістрант факультету управління прочесами перевезень Українського державного університету залізничного транспорту, м. Харків, Украӥна.

Пархоменко Лариса Олексіївна, канд. техн. наук, дочент, кафедра управління експлуатаційною роботою Українського державного університету залізничного транспорту, м. Харків, Україна. E-mail: l.o.parkhomenko@ukr.net ORCID: http://org/0000-0003$\underline{1647-7746}$

Yevhen Parkhomenko, magistrate of the Faculty of Transportation Transportation Management, Ukrainian State University of Railway Transport, Kharkiv, Ukraine.

Larysa Parkhomenko, PhD, Associate Professor, Department of Operational Management of the Ukrainian State University of Railway Transport, Kharkiv, Ukraine. E-mail: l.o.parkhomenko@ukr.net ORCID: http: // org / 0000-0003-1647-7746 